\title{
STOSOWANIE PRZEZ SĄDY ADMINISTRACYJNE STANDARDÓW EUROPEJSKICH W TOKU ROZSTRZYGANIA TRANSGRANICZNYCH PROBLEMÓW OBYWATELSTWA ORAZ TRANSKRYPCJI AKTÓW STANU CYWILNEGO
}

\begin{abstract}
Streszczenie. Sprawy dotyczące transkrypcji zagranicznego aktu urodzenia dziecka, w którym jako rodzice wpisane są osoby tej samej płci, oraz potwierdzenia posiadania przez takie dziecko obywatelstwa polskiego od kilku lat pozostają na wokandzie polskich sądów administracyjnych. Zagadnienie dopuszczalności umieszczenia w polskich księgach stanu cywilnego wpisu osób tej samej płci, jako rodziców dziecka, ma ważkie znaczenie w kontekście kształtowania stosunków społecznych i relacji rodzinnych oraz roli prawa pozytywnego, jako ich regulatora w dynamicznie zmieniającej się rzeczywistości społecznej. Rozstrzygając w sprawach tego rodzaju, sądy stają przed koniecznością rozwiązywania konfliktów czy kolizji nie tylko norm (zasad i wartości) prawa krajowego, ale także kolizji systemów prawnych. W procesie sądowego stosowania prawa ważenia wymagają, z jednej strony, zasada ochrony praw dziecka, a z drugiej - inne podstawowe zasady porządku prawnego Rzeczypospolitej Polskiej, tj. fundamentalne zasady ustroju społeczno-politycznego (zwłaszcza wynikająca $\mathrm{z}$ art. 18 Konstytucji zasada ochrony małżeństwa jako związku kobiety i mężczyzny, rodziny, macierzyństwa i rodzicielstwa) oraz naczelne zasady rządzące poszczególnymi dziedzinami prawa cywilnego, rodzinnego czy procesowego. Dobro dziecka to konstytucyjna klauzula generalna, której wykładnia powinna odbywać się przez odwołanie do aksjologii konstytucyjnej i całokształtu systemu prawa. Nakaz ochrony dobra dziecka stanowi też nadrzędną zasadę polskiego systemu prawa rodzinnego, której podporządkowane są wszelkie regulacje w sferze stosunków pomiędzy rodzicami i dziećmi. Ważkość tych materii sprawiła, że w orzecznictwie pojawiły się rozbieżności co do dopuszczalności owej transkrypcji z uwagi na klauzulę porządku publicznego. Skład siedmiu sędziów NSA w uchwale II OPS 1/19 przesądził jednak, że polskie prawo nie dopuszcza transkrypcji zagranicznego aktu urodzenia dziecka, w którym jako rodzice wpisane są osoby tej samej płci.

Słowa kluczowe: transkrypcja zagranicznego aktu stanu cywilnego, dobro dziecka, obywatelstwo, prawo do prywatności, zakaz dyskryminacji, wartości konstytucyjne, klauzula porządku publicznego, podstawowe zasady porządku prawnego Rzeczypospolitej Polskiej, konstytucyjna zasada ochrony małżeństwa i rodziny.
\end{abstract}

* Uniwersytet Łódzki, Wydział Prawa i Administracji, Katedra Prawa Konstytucyjnego, achmielarz@wpia.uni.lodz.pl. 


\title{
EUROPEAN STANDARDS APPLIED BY ADMINISTRATIVE COURTS IN RESOLVING CROSS-BORDER PROBLEMS OF CITIZENSHIP AND TRANSCRIPTION OF CIVIL STATUS CERTIFICATES
}

\begin{abstract}
The cases concerning transcription of a child's foreign birth certificate, in which the registered parents are persons of the same sex, as well as confirmation of Polish citizenship by such a child, have been in the field of judicial cognition of Polish administrative courts for just several years. The issue of admissibility registering same-sex couples as parents of a child in Polish registry office has gained the great importance in the context of shaping social and family relations and the role of positive law as their regulator in dynamic society. When deciding such, the courts face the necessity to resolve not solely conflicts of norms (principles and values) within the domestic law, but also conflicts of legal systems. In the process of judicial application of law there is a need for balancing - on the one hand - the principle of the protection of the rights of a child, and - on the other one - other principles basic to the Polish legal order, i.e. the fundamental principles of the socio-political system (especially the principle of protection of marriage as a liaison of a men and a woman as well as the protection of family, motherhood and parenthood that arise from the art. 18 of Polish Constitution) and the general principles governing particular areas of civil, family and procedural law. The child's welfare is a general constitutional clause that shall be interpreted with the reference to the constitutional axiology and to the entire legal system. The protection the child's best interests is also the overriding principle of the Polish family law, and governs all of the regulations in the area of relations between parents and children. The important and delicate nature of this matter caused the discrepancies in the jurisprudence due to admissibility of such transcription in the light of the public order clause. The panel of seven judges of the Supreme Administrative Court, in Resolution No. II OPS 1/19, determined that Polish law did not allow the transcription of a foreign birth certificate showing same-sex persons as parents.

Keywords: transcription of a foreign civil status certificate, child's welfare, citizenship, right to privacy, non-discrimination, constitutional values, public order clause, basic principles of legal order of the Republic of Poland, constitutional principle of protection of marriage and family.
\end{abstract}

\section{WPROWADZENIE}

Obecnie sądy krajowe funkcjonują w wieloskładnikowej przestrzeni prawnej, co jest efektem współobowiązywania w polskim systemie prawa norm prawnych tworzonych w różnych centrach prawodawczych (Łętowska 2005a, 3-10; 2005b, 3-10; Hauser, Niewiadomski, Wróbel 2012, 124-125). Jednocześnie rozstrzygania wymagają problemy prawne związane z takimi zjawiskami, jak: otwarte granice i ruchy migracyjne, pluralizm stylów życia, rozwój technologii informacyjnych i medycznych. Wskazane zjawiska stanowią źródło m.in. transgranicznych problemów obywatelstwa i transkrypcji zagranicznych aktów stanu cywilnego. Zagadnienia prawa osobowego i rodzinnego oraz - będąca ich odzwierciedleniem - rejestracja aktu urodzenia dziecka, jak również zagadnienia publicznoprawne dotyczące obywatelstwa podlegają ustawodawstwu poszczególnych państw. Ustawodawstwa te różnią się między sobą, co nierzadko prowadzi do transgranicznych 
problemów w konkretnych i indywidualnych przypadkach. Stosowanie prawa w takich przypadkach oznacza konieczność rozstrzygania kolizji zarówno normatywnych, jak i interpretacyjnych, których źródłem jest konflikt i/lub konkurencja wartości prawem chronionych oraz ich tradycyjnego bądź współczesnego rozumienia ${ }^{1}$.

W ostatnich latach na wokandzie polskich sądów administracyjnych pojawiały się sprawy dotyczące odmowy poświadczenia obywatelstwa oraz transkrypcji aktów urodzenia dzieci urodzonych i wychowywanych przez rodziców jednopłciowych, w których co najmniej jedno z rodziców posiada obywatelstwo polskie, lecz ich zawarty za granicą związek nie wywołuje w Polsce skutków prawnych (Mostowik 2019). Sprawy dotyczące przeniesienia owego zagranicznego aktu urodzenia do polskiego rejestru stanu cywilnego oraz potwierdzenia obywatelstwa polskiego wobec takiego dziecka są ze sobą funkcjonalnie powiązane. Posłużenie się wyłącznie zagranicznym aktem urodzenia nie wystarczy bowiem, by dziecku wydany został polski dokument tożsamości. Zagraniczny akt urodzenia przenieść należy do polskiego obrotu prawnego, tj. rejestru aktów stanu cywilnego. Co więcej, rejestracja w polskich aktach stanu cywilnego pochodzenia dziecka od dwóch osób tej samej płci ma doniosłe znaczenie zarówno z punktu widzenia statusu jednostki w państwie (jej praw i wolności, ich przestrzegania oraz ochrony), jak również spójności polskiego systemu prawnego ze standardami prawa międzynarodowego i prawa Unii Europejskiej. Zagadnienie dopuszczalności umieszczenia w polskich księgach stanu cywilnego wpisu osób tej samej płci, jako rodziców dziecka, ma poza tym ważkie znaczenie w kontekście kształtowania stosunków społecznych i relacji rodzinnych oraz roli prawa pozytywnego jako ich regulatora.

Polskie sądy administracyjne, orzekając w sprawach tego rodzaju, współstosują Konwencję o ochronie praw człowieka i podstawowych wolności², jak również biorą pod uwagę wypracowany na jej podstawie acquis conventionnel, w tym zwłaszcza utrwalone orzecznictwo Europejskiego Trybunału Praw Człowieka (ETPC). Decyzje dotyczące poświadczenia czy odmowy poświadczenia obywatelstwa, a także dokonania lub odmowy dokonania transkrypcji aktu stanu cywilnego mogą w istotny sposób ingerować w prawa zagwarantowane Konwencją. Chodzi tu o prawo do poszanowania życia prywatnego i rodzinnego (art. 8) oraz subsydiarny zakaz dyskryminacji w związku z realizacją innych praw konwencyjnych (art. 14). Sądy stosują także wiążące Polskę prawo międzynarodowe

${ }^{1} \mathrm{~W}$ odniesieniu do praktyki stosowania prawa przez sądy administracyjne zob. Chmielarz-Grochal, Kalisz 2020, 71-94.

${ }^{2}$ Konwencja o ochronie praw człowieka i podstawowych wolności sporządzona w Rzymie dnia 4 listopada 1950 r., zmieniona następnie Protokołami nr 3, 5 i 8 oraz uzupełniona Protokołem nr 2 (Dz. U. z 1993 r., nr 61, poz. 284, ze zm.). 
publiczne, w tym zasadę nadrzędnego interesu dziecka $\mathrm{z}$ art. 3 ust. 1 Konwencji o prawach dziecka ${ }^{3}$. Zgodnie z tym przepisem

we wszystkich działaniach dotyczących dzieci, podejmowanych przez publiczne lub prywatne instytucje opieki społecznej, sądy, władze administracyjne lub ciała ustawodawcze, sprawą nadrzędną będzie najlepsze zabezpieczenie interesów dziecka.

Pod uwagę brany jest także art. 7 ustawy z dnia 4 lutego 2011 r. - Prawo prywatne międzynarodowe (Dz. U. z 2015 r., poz. 1792), zawierający tzw. klauzulę porządku publicznego, zgodnie z którą prawa obcego nie stosuje się, jeżeli jego stosowanie miałoby skutki sprzeczne z podstawowymi zasadami porządku prawnego Rzeczypospolitej Polskiej. Klauzula ta stanowi wyjątek od generalnej zasady uznawania i stosowania prawa obcego.

Jak pokazuje praktyka, w tego typu sprawach dochodzi do konfliktu i/lub konkurencji wartości chronionych nie tylko prawem konstytucyjnym, ale także wartości o charakterze uniwersalnym. Ważenia wymagają konstytucyjnie chroniona różnopłciowość związków małżeńskich (art. 18 Konstytucji RP) oraz prawo każdego dziecka do obywatelstwa (art. 24 ust. 3 Międzynarodowego Paktu Praw Obywatelskich i Politycznych) i nadrzędność interesu dziecka (art. 3 ust. 1 Konwencji o prawach dziecka). Konstytucja Rzeczypospolitej Polskiej również nakłada na państwo, a więc wszystkie organy władzy publicznej, obowiązek ochrony praw dziecka (art. 72 ust. 1). Rozstrzyganie takich spraw wymaga zatem nie tylko operatywnego stosowania norm ustanowionych w różnych centrach prawodawczych, ale również - co wydaje się kluczowe - ważenia leżących u podstaw tych norm wartości. Trzeba przy tym pamiętać, że w ramach kontroli legalności aktu administracji publicznej polskie sądy administracyjne dokonują badania (oceny) w zakresie odnoszącym się do kompetencyjno-proceduralnych podstaw działania organu podejmującego rozstrzygnięcie oraz materialnoprawnych podstaw jego wydania. W tym drugim aspekcie sądy kontrolują prawidłowość wykładni normatywnych podstaw wydania aktu administracyjnego oraz prawidłowość ich zastosowania (Leszczyński 2010, 267-279).

\section{STANDARDY WYPRACOWANE W ORZECZNICTWIE EUROPEJSKIEGO TRYBUNAŁU PRAW CZLOWIEKA}

Zagadnienia obywatelstwa oraz transkrypcji zagranicznych aktów urodzenia dzieci, w których jako rodzice figurują osoby tej samej płci, objęte są jurysdykcją Europejskiego Trybunału Praw Człowieka. Jednakże tylko częściowo - i pośrednio - mieszczą się w zakresie regulacji Konwencji o ochronie praw człowieka i podstawowych wolności. Wskazane zagadnienia z istoty swojej związane

${ }^{3}$ Konwencja o prawach dziecka przyjęta przez Zgromadzenie Ogólne Narodów Zjednoczonych dnia 20 listopada 1989 r. (Dz. U. z 1991 r., nr 120, poz. 526, ze zm.). 
są bowiem z przyjętymi przez państwa zasadami/regułami nabywania obywatelstwa, jego poświadczenia oraz z systemem rejestracji stanu cywilnego. Nie ma natomiast wątpliwości, że wskazane kwestie dotykają sfery prywatności człowieka, a Konwencja gwarantuje każdemu prawo do poszanowania życia prywatnego i rodzinnego (art. 8).

W dotychczasowym orzecznictwie ETPC odwoływał się do relacji między prawem do obywatelstwa a zdolnością do korzystania z prawa do życia prywatnego. Po raz pierwszy odniósł się do tej kwestii w decyzji w sprawie Karassev przeciwko Finlandii ${ }^{4}$, w którym stwierdził, że ,,arbitralna odmowa obywatelstwa może w pewnych okolicznościach łączyć się z naruszeniem art. 8 EKPC, ponieważ skutki takiej odmowy dotyczą życia prywatnego jednostki”. Trybunał potwierdził związek instytucji obywatelstwa $\mathrm{z}$ art. 8 Konwencji także w wyroku w sprawie Kurić i inni przeciwko Stowenii ${ }^{5}$. W wyroku w sprawie Genovese przeciwko Mal$c i e^{6}$ Trybunał stwierdził, że odmowa obywatelstwa może łączyć się z naruszeniem art. 8 EKPC ze względu na wpływ na życie prywatne jednostki, co obejmuje również tożsamość społeczną jednostki.

W wyrokach Mennesson przeciwko Francji $i^{7}$ oraz Labasse przeciwko Francji ${ }^{8}$ Trybunał uznał, że niepewność dzieci urodzonych przez matkę-surogatkę w zakresie uznania ich (w tym przypadku francuskiego) obywatelstwa mogła mieć negatywne reperkusje w zakresie ich osobistej tożsamości, a tym samym stanowiła naruszenie ich prawa do poszanowania życia prywatnego. W sprawie Mennesson Trybunał uznał, że odmowa uznania prawnej więzi rodzic-dziecko (która również wpłynęła na obywatelstwo dziecka) była niezgodna z zasadą najlepszego interesu dziecka wywiedzioną z art. 3 ust. 1 Konwencji o prawach dziecka, stanowiła także przekroczenie przez państwo granic tzw. marginesu oceny w stosunku do art. 8 Konwencji. Przytoczona linia orzecznicza Trybunału dotyczyła związku prawnego między dzieckiem urodzonym przez matkę-surogatkę a ojcem biologicznym.

W dniu 10 kwietnia 2019 r., na podstawie Protokołu nr 16 do Konwencji, na wniosek francuskiego Sądu Kasacyjnego (wniosek nr P16-2018-001) Trybunał w składzie wielkiej izby wydał opinię doradczą, która dotyczyła sytuacji faktycznej i prawnej rodziny Mennesson. W sprawie tej odmówiono dwojgu dzieciom

\footnotetext{
${ }^{4}$ Decyzja ETPC z dnia 12 stycznia 1999 r. w sprawie Karassev przeciwko Finlandii, skarga nr 31414/96, HUDOC.

${ }^{5}$ Wyrok ETPC z dnia 12 marca 2014 r. w sprawie Kurić i inni przeciwko Słowenii, skarga nr 26828/06, HUDOC.

${ }^{6}$ Wyrok ETPC z dnia 11 października 2011 r. w sprawie Genovese przeciwko Malcie, skarga nr 53124/09, HUDOC.

${ }^{7}$ Wyrok ETPC z dnia 26 czerwca 2014 r. w sprawie Mennesson przeciwko Francji, skarga nr 65192/11, HUDOC.

${ }^{8}$ Wyrok ETPC z dnia 26 czerwca 2014 r. w sprawie Labasse przeciwko Francji, skarga nr 65941/11, HUDOC.

${ }^{9}$ Zob. omówienie opinii - Florjanowicz-Błachut 2020, 107-118.
} 
urodzonym w Kalifornii przez matkę zastępczą (surogatkę) w wyniku połączenia gamet ojca biologicznego (małżonka Mennesson) i anonimowej dawczyni uznania prawnej relacji rodzic-dziecko w stosunku zarówno do biologicznego ojca, jak i do tzw. matki intencyjnej, która - będąc żoną pana Mennesson - nie miała jednak genetycznego związku z dziećmi. Trybunał w opinii doradczej stwierdził, że w świetle art. 8 Konwencji prawo krajowe musi przewidywać możliwość prawnego uznania relacji między dzieckiem urodzonym przez matkę-surogatkę a kobietą wpisaną w zagranicznym akcie urodzenia jako jego matka. Uznanie to nie musi jednak polegać na zarejestrowaniu kobiety jako matki dziecka $\mathrm{w}$ aktach stanu cywilnego. Państwo może przewidzieć w tym celu inne środki prawne - takie jak np. umożliwienie kobiecie adopcji dziecka - pod warunkiem, że środki te są skuteczne, szybkie oraz realizowane zgodnie z interesem dziecka. Trybunał podkreślił, że w sprawach dotyczących dzieci zawsze należy kierować się zasadą najlepszego interesu dziecka. Odmowa uznania przez państwo relacji między dzieckiem urodzonym przez matkę-surogatkę a kobietą wpisaną do zagranicznego aktu urodzenia jako jego matka negatywnie oddziałuje na jego prawa. Dziecko takie może być bowiem pozbawione poczucia tożsamości, prawa do uzyskania obywatelstwa matki, dziedziczenia po niej, utrzymywania z nią kontaktu po ewentualnym rozwodzie z ojcem dziecka, a także napotykać trudności w uzyskaniu prawa pobytu w państwie zamieszkania matki. Prawo krajowe powinno zatem przewidywać inne formy prawne uznania relacji pomiędzy dzieckiem a matką intencyjną. Nie ma przy tym znaczenia, czy dziecko zostało poczęte przy użyciu jej komórek jajowych, choć jeżeli tak się stało, to potrzeba formalnego uznania relacji rodzic-dziecko jest jeszcze wyraźniejsza.

Trybunał - zważywszy na brak w tej kwestii ogólnoeuropejskiego konsensusu - potwierdził pewną swobodę (margines uznania) państwa przy wyborze środków czy form prawnego uznania tej relacji. Co do zasady z Konwencji nie można wywieść obowiązku dokonania całościowej transkrypcji zagranicznego aktu urodzenia dziecka urodzonego przez matkę-surogatkę. Państwo może więc skorzystać z innych rozwiązań, aby nie pozostawiać dziecka w stanie niepewności prawnej.

Kwestie odmowy poświadczenia obywatelstwa oraz transkrypcji zagranicznego aktu urodzenia dziecka, w którym jako rodzice wpisane są osoby tej samej płci, stały się przedmiotem skarg indywidualnych wnoszonych do ETPC również przeciwko Polsce. W 2019 r. rządowi polskiemu zostały zakomunikowane m.in.: 1) sprawa Schlittner-Hay (skargi nr 56846/15 i 56849/15), dotycząca odmowy poświadczenia obywatelstwa polskiego ${ }^{10}$, oraz 2) sprawa A. D.-K. i inni (skarga nr 30806/15), dotycząca odmowy transkrypcji aktu urodzenia dziecka ${ }^{11}$.

${ }^{10}$ Zob. https://hudoc.echr.coe.int/eng\#\{\%22itemid\%22:[\%22001-192050\%22]\} [dostęp: 15.03.2020].

${ }^{11}$ Zob. https://hudoc.echr.coe.int/eng\#\{\%22itemid\%22:[\%22001-192049\%22]\} [dostęp: 15.03.2020]. 
Skargi oparto na zarzutach naruszenia art. 8 i art. 14 w zw. z art. 8 Konwencji. W sprawach tych, w ramach krajowych środków prawnych, orzekały sądy administracyjne.

\section{SĄDY ADMINISTRACYJNE WOBEC PROBLEMU TRANSKRYPCJI ZAGRANICZNEGO AKTU URODZENIA DZIECI OSÓB POZOSTAJACYCY W ZWIĄZKACH JEDNOPLCIOWYCH}

Zagadnienie transkrypcji zagranicznego aktu urodzenia, w którym jako rodzicie dziecka figurują osoby tej samej płci, wywołało poważne wątpliwości w procesie stosowania prawa w kontekście podstawowych zasad porządku prawnego Rzeczypospolitej Polskiej. Dotyczyły one również przypadków odmowy transkrypcji zagranicznego aktu urodzenia dziecka, który nie zawierał danych matki (w przypadkach surogacji). Analogiczne wątpliwości pojawiały się w sprawach odmowy poświadczenia obywatelstwa dzieci, w których zagranicznych aktach urodzenia jako rodzice wpisane były osoby tej samej płci albo nie wpisano danych matki. W efekcie powstały rozbieżności w orzecznictwie sądów administracyjnych i ukształtowały się dwa odmienne nurty orzecznicze.

Pierwszy z nich opiera się na poglądzie, że wpisanie do polskich ksiąg stanu cywilnego treści zagranicznego aktu urodzenia, który obok matki (ojca) dziecka, jako drugiego rodzica wymienia osobę tej samej płci, stanowiłoby pogwałcenie podstawowych zasad polskiego porządku prawnego. Sądy powołują się na wyrażoną w art. 7 ustawy - Prawo prywatne międzynarodowe klauzulę porządku publicznego. Stanowisko takie zostało zaprezentowane w wyrokach NSA ${ }^{12}$ : z dnia 17 grudnia 2014 r., II OSK 1298/13 i z dnia 20 czerwca 2018 r., II OSK 1808/16 oraz wyrokach wojewódzkich sądów administracyjnych: wyroku WSA w Gliwicach z dnia 6 kwietnia 2016 r., II SA/G1 1157/15; wyroku WSA w Krakowie z dnia 10 maja 2016 r., III SA/Kr 1400/15; wyroku WSA w Warszawie z dnia 14 kwietnia 2016 r., IV SA/Wa 182/16. W orzeczeniach tych zwraca się uwagę na następujące kwestie.

Po pierwsze, sądy administracyjne przyjmują, że przepisy obowiązujące na terenie Rzeczypospolitej Polskiej nie przewidują ani możliwości usankcjonowania związku osób tej samej płci, ani możliwości przysposobienia dziecka przez osoby tej samej płci, co zgodnie z przepisami kodeksu rodzinnego i opiekuńczego ${ }^{13}$ uczynić wspólnie mogą tylko małżonkowie. Pojęcia „rodzicielstwo” oraz „rodzice” w obowiązującym prawie odnoszą się do osób różnej płci (kobiety i mężczyzny), co potwierdza art. 18 Konstytucji. Przepis ten stanowi, że małżeństwo, jako związek kobiety i mężczyzny, rodzina, macierzyństwo i rodzicielstwo

${ }^{12}$ Przywoływane w tekście orzeczenia sądów administracyjnych dostępne są na: http:// orzeczenia.nsa.gov.p1/ [dostęp: 15.03.2020].

${ }^{13}$ Ustawa z dnia 25 lutego 1964 r. - Kodeks rodzinny i opiekuńczy (Dz. U. z 2020 r., poz. 1359). 
znajdują się pod ochroną i opieką Rzeczypospolitej Polskiej. Wyraża on konstytucyjną zasadę ochrony małżeństwa i rodziny (Borysiak 2016, 464-495; Garlicki 2016, 489-505).

Po drugie, zdaniem sądów, przy rozstrzyganiu sprawy transkrypcji zagranicznego aktu urodzenia dziecka, w którym jako rodzice wpisane są osoby tej samej płci, znaczenie ma dostrzegalna sprzeczność pomiędzy zewnętrzną formą zagranicznego wzoru aktu urodzenia a wzorem jego polskiego odpowiednika (zawierającym rubrykę ,matka” i rubrykę „ojciec”). Sądy zwracają uwagę na art. 104 ustawy z dnia 28 listopada 2014 r. - Prawo o aktach stanu cywilnego (Dz. U. z 2020 r., poz. 463 , ze zm.), zgodnie z którym ,transkrypcja polega na wiernym i literalnym przeniesieniu treści zagranicznego dokumentu stanu cywilnego zarówno językowo, jak i formalnie, bez żadnej ingerencji w pisownię imion i nazwisk osób wskazanych w zagranicznym dokumencie stanu cywilnego".

W wyroku II OSK 1298/13 NSA podniósł, że w kwestii tej nie chodzi wyłącznie o wzory druków, gdyż nawet gdyby druki miały rubrykę ,,rodzic”, to przez „rodziców” rozumie się w Polsce w sposób jednoznaczny ojca i matkę. Dlatego - zdaniem NSA - w aktualnym stanie prawnym niedopuszczalne jest wpisanie do aktu stanu cywilnego dwóch osób tej samej płci, jako ojca i matki lub jako rodziców, niezależnie od sposobu oznaczenia poszczególnych rubryk we wzorze aktu. Co więcej, w ocenie NSA, taka wykładnia pojęcia rodzicielstwa nie narusza przepisów Traktatu o funkcjonowaniu Unii Europejskiej i Karty Praw Podstawowych. Sąd zwrócił ponadto na orzecznictwo ETPC, z którego wynika, że państwom wolno ograniczać dostęp do związków małżeńskich parom osób tej samej płci ${ }^{14}$, co odnosi się również do związków partnerskich.

Po trzecie, sądy administracyjne stoją na stanowisku, że w sprawach odmowy wpisania do akt stanu cywilnego zagranicznego aktu urodzenia dziecka, w którym jako rodzice są wpisane osoby tej samej płci, nie można dopatrzyć się pobudek dyskryminacyjnych (ze względu na orientację seksualną) lub naruszenia zasady równości obywateli wobec prawa. Sądy nie podzielają poglądu, że odmowa dokonania transkrypcji uniemożliwia dziecku skutecznie wykazanie i ustalenie przed polskimi organami i sądami podstawowego elementu swojej tożsamości w postaci relacji z jednym ze swoich rodziców. W tym zakresie powołują się na art. 1138 Kodeksu postępowania cywilnego ${ }^{15}$, który przyznaje zagranicznym dokumentom urzędowym moc dowodową na równi z polskimi dokumentami urzędowymi i nie wprowadza jakichkolwiek dodatkowych wymogów, w szczególności wymogu transkrypcji tych dokumentów.

W wyroku II OSK 1808/16 NSA, odnosząc się do zarzutu naruszenia zasady równego traktowania oraz naruszenia zasady ochrony praw dziecka przez jego

${ }^{14}$ Wyrok ETPC z dnia 24 czerwca 2010 r., Schalk i Kopf przeciwko Austrii, skarga nr 30141/04, HUDOC.

${ }^{15}$ Ustawa z dnia 17 listopada 1974 r. - Kodeks postępowania cywilnego (Dz. U. z 2020 r., poz. 1575 , ze zm.). 
nieuzasadnioną dyskryminację, wprost uznał, że w sprawie odmowy transkrypcji aktu urodzenia dziecka pochodzącego ze związku jednopłciowego nie miały zastosowania przepisy dotyczące obywatelstwa, prawa posiadania dokumentu tożsamości, ustawy o dokumentach paszportowych. Skład orzekający podkreślił, że do właściwości sądu administracyjnego nie należy orzekanie w sprawach równego traktowania.

Odmienny nurt orzeczniczy wyraźnie zapoczątkował NSA wyrokiem z dnia 10 października 2018 r., II OSK 2552/16. Skład orzekający w tej sprawie uznał, że odmowa transkrypcji aktu urodzenia narusza prawa dziecka w kontekście gwarancji wynikających z EKPC i Konwencji o prawach dziecka. Sąd dokonał swoistego „ważenia zasad i wartości”, dając pierwszeństwo szeroko rozumianej klauzuli dobra (interesu) dziecka przed wąsko rozumianą klauzulą porządku publicznego, stanowiącą wyjątek w sytuacji realnego i poważnego zagrożenia dla jednego z podstawowych interesów społeczeństwa, którego nie dopatrzył się $\mathrm{w}$ rozpatrywanym przypadku.

Instytucja transkrypcji obligatoryjnej to - w ocenie NSA - kluczowe źródło obowiązku przeniesienia do polskiego rejestru stanu cywilnego zagranicznego aktu urodzenia małoletniego obywatela polskiego, niezależnie od tego, że w akcie tym jako rodziców wskazano dwie kobiety. Sąd podkreślił, że odmowa dokonania transkrypcji ze względu na klauzulę porządku publicznego nie jest zgodna z przepisami prawa, gdyż prowadzi do naruszenia zasady transkrypcji obligatoryjnej, tj. obowiązku wynikającego z art. 104 ust. 5 ustawy - Prawo o aktach stanu cywilnego ${ }^{16}$. Zwrócił również uwagę, że instytucję transkrypcji obligatoryjnej wprowadzono m.in. w celu wykluczenia sytuacji, w których obywatelowi Rzeczypospolitej Polskiej nie zostałyby wydane dokumenty poświadczające jego tożsamość. Sąd stwierdził, że

nie jest zgodne z obowiązującymi przepisami prawa takie działanie, aby poprzez klauzulę porządku publicznego, odmawiać transkrypcji ze względu na porządek publiczny (transkrypcja fakultatywna $z$ art. 107 pkt 3 ustawy Prawo o aktach stanu cywilnego) i tym samym nie realizować obowiązku wynikającego z ustawy (transkrypcja obligatoryjna z art. 104 ust. 5 ustawy Prawo o aktach stanu cywilnego).

Co więcej, zdaniem NSA, „ustawowy obowiązek transkrypcji zagranicznego aktu stanu cywilnego, prowadzący do poświadczenia tożsamości dziecka, wpisuje się w cały system ochrony praw dziecka”. Sąd odwołał się

${ }^{16} \mathrm{Z}$ treści art. 104 ust. 5 ustawy Prawo o aktach stanu cywilnego wynika, że transkrypcja jest obligatoryjna, jeżeli obywatel polski, którego dotyczy zagraniczny dokument stanu cywilnego, posiada akt stanu cywilnego potwierdzający zdarzenia wcześniejsze sporządzony na terytorium Rzeczypospolitej Polskiej i żąda dokonania czynności z zakresu rejestracji stanu cywilnego lub ubiega się o polski dokument tożsamości lub nadanie numeru PESEL. Zgodnie zaś z art. 107 pkt 3 ustawy Prawo o aktach stanu cywilnego kierownik urzędu stanu cywilnego odmawia dokonania transkrypcji, jeżeli transkrypcja byłaby sprzeczna z podstawowymi zasadami porządku prawnego Rzeczypospolitej Polskiej. 
do orzecznictwa ETPC, który wielokrotnie podkreślał, że w przypadku, w którym wchodzi w grę sytuacja dziecka, to interes dziecka musi przeważać. Przy dokonywaniu oceny sytuacji dziecka również pod względem prawym poszanowanie praw dziecka powinno stanowić główną wytyczną decyzji ${ }^{17}$. Poza tym, jak zwracał uwagę ETPC, dziecko, wobec którego odmówiono transkrypcji aktu urodzenia, znajduje się w sytuacji niepewności co do swojego statusu prawnego, a jego związek z rodzicami ustalonymi w zagranicznym akcie urodzenia jest nierozpoznany przez porządek prawny ${ }^{18}$.

Skład orzekający w tej sprawie, nie kwestionując zasadności zastosowania klauzuli porządku publicznego in genere, wskazał, że

pojęcie porządku publicznego jako uzasadnienie odstępstwa od podstawowego działania polegającego na dokonaniu transkrypcji powinno być interpretowane w sposób wąski, odnoszący się szczegółowo do realiów rozpatrywanej sprawy oraz wnikliwie oceniający realne i poważne zagrożenia dla jednego z podstawowych interesów społeczeństwa w konkretnym przypadku.

Powołał się w tym kontekście na utrwalone orzecznictwo TSUE - wyroki w sprawie C-438/14 Bogendorff von Wolffersdorff ${ }^{19}$ oraz w sprawie C-193/16 E przeciwko Subdelegación del Gobierno en Álava ${ }^{20}$.

Odnosząc się do realiów niniejszej sprawy, NSA uznał, że obowiązek transkrypcji określony w art. 104 ust. 5 ustawy, realizowany wyłącznie w celu ochrony praw dziecka poprzez umożliwienie mu poświadczenia jego tożsamości, nie stoi w sprzeczności z zasadami porządku publicznego. Sąd nawiązał do wyroku TSUE w sprawie C-673/16 Coman ${ }^{21}$, w którym Trybunał przesądził definitywnie, że obowiązek uznania małżeństwa tej samej płci wyłącznie do celów przyznania pochodnego prawa pobytu obywatelowi państwa trzeciego nie narusza tożsamości narodowej ani nie zagraża porządkowi publicznemu danego państwa członkowskiego.

Należy zaznaczyć, że wcześniej podobne stanowisko zajął WSA w Poznaniu, który w wyroku z dnia 5 kwietnia 2018 r., II SA/Po 1169/17 stwierdził, że transkrypcja zagranicznego aktu urodzenia jest obligatoryjna na mocy art. 104 ust. 5 ustawy - Prawo o aktach stanu cywilnego oraz ze względu na obowiązek ochrony praw dziecka, a sądy powinny dokonywać wykładni przepisów tak, aby jej rezultat był zgodny z Konstytucją RP, wiążącymi Polskę przepisami prawa

${ }^{17}$ Wyrok ETPC z dnia 26 czerwca 2014 r., Mennesson przeciwko Francji, skarga nr 65192/11 i przywołane tam orzecznictwo, HUDOC.

${ }^{18}$ Wyrok ETPC z dnia 26 czerwca 2014 r., Labassee przeciwko Francji, skarga nr 65941/11, HUDOC.

${ }^{19}$ Wyrok TSUE z dnia 2 czerwca 2016 r. w sprawie C-438/14 Bogendorff von Wolffersdorff, ECLI:EU:C:2016:401, pkt 67 i przytoczone tam wcześniejsze orzecznictwo.

${ }^{20}$ Wyrok TSUE z dnia 13 lipca 2017 r. w sprawie C-193/16 E przeciwko Subdelegación del Gobierno en Álava, ECLI:EU:C:2017:542, pkt 18 i przytoczone tam wcześniejsze orzecznictwo.

${ }^{21}$ Wyrok TSUE z dnia 5 czerwca 2018 r. w sprawie C-673/16 Coman, ECLI:EU:C:2018:385. 
międzynarodowego, a także ich aksjologicznym uzasadnieniem. Odmowa dokonania transkrypcji, zdaniem składu orzekającego w tej sprawie, powoduje z kolei

niemożność nadania numeru PESEL oraz uzyskania polskiego dokumentu tożsamości, a to z kolei wywołuje skutek w postaci ograniczenia dostępu do polskiego systemu oświaty, czy też polskiego systemu opieki zdrowotnej. Ponadto polski obywatel nieposiadający dokumentu tożsamości nie ma możliwości podróżowania do innych państw. Powyższe ograniczenia niewątpliwie stanowią naruszenie podstawowych praw związanych z posiadaniem obywatelstwa polskiego. Niewątpliwie natomiast dziecko, którego rodzicami są polscy obywatele, także posiada obywatelstwo polskie.

Ponadto, NSA wyrokiem z dnia 29 sierpnia 2018 r., II OSK 2129/16, wydanym w sprawie dotyczącej transkrypcji zagranicznego aktu urodzenia dziecka urodzonego przy wykorzystaniu procedury in vitro i umowy o macierzyństwo zastępcze (tzw. surogacji), uchylił zaskarżone orzeczenie i poprzedzające je decyzje organów administracji odmawiające transkrypcji ze względu na klauzulę porządku publicznego. Swoje rozstrzygnięcie NSA uzasadnił tym, że uchylone orzeczenie sądu pierwszej instancji oraz wcześniejsze decyzje administracyjne stały w sprzeczności z obowiązkiem ochrony praw dziecka, wyrażonym zarówno w Konstytucji, jak i Konwencji o prawach dziecka. W uzasadnieniu wyroku NSA odniósł się także do szczególnych praw podmiotowych przysługujących osobom posiadającym obywatelstwo polskie. Podkreślił, że odmowa dokonania transkrypcji aktu urodzenia skutkowałaby niemożnością uzyskania przez małoletniego obywatela polskiego dokumentu potwierdzającego tożsamość, a tym samym uniemożliwiłaby mu korzystanie z praw wynikających z obywatelstwa. Sąd przywołał postanowienie Sądu Najwyższego z dnia 8 maja 2015 r., III CSK 296/14 (LEX nr 1712817), w którym poddano szczegółowej analizie techniczny oraz funkcjonalny wymiar zagranicznego aktu stanu cywilnego w systemie krajowym. Zgodnie ze stanowiskiem Sądu Najwyższego

[w]ierne oraz literalne odtworzenie treści zagranicznego aktu stanu cywilnego w polskiej księdze stanu cywilnego musi być dokonywane z uwzględnieniem znaczenia poszczególnych elementów jego treści. Powinny one być przenoszone do polskich ksiąg stanu cywilnego zgodnie nie tylko z ich brzmieniem, ale także funkcją, którą pełnią. Wpisy zawarte w zagranicznym akcie stanu cywilnego powinny więc być przenoszone w taki sposób, aby w polskich księgach stanu cywilnego i w powstałym w wyniku transkrypcji polskim akcie stanu cywilnego zachowały swoją tożsamość nie tylko pod względem ich brzmienia, ale także funkcji.

W wyroku II OSK 2129/16 NSA odwołał się także do przepisów prawa unijnego, zwracając uwagę, że odmowa transkrypcji aktu urodzenia uniemożliwia uzyskanie paszportu, co z kolei może ograniczać lub wręcz wykluczyć podróżowanie do innych państw. Ma to, w ocenie NSA, szczególne znaczenie w kontekście przynależności Polski do Unii Europejskiej i wynikających z tego faktu uprawnień dla osób posiadających polskie obywatelstwo. Jak stwierdził NSA, 
niewątpliwie [...] polski dokument paszportowy zaświadcza o posiadaniu polskiego obywatelstwa, a w konsekwencji także obywatelstwa UE, w wyniku czego jego posiadacz może korzystać m.in. ze swobody przepływu osób zgodnie z Traktatem o funkcjonowaniu Unii Europejskiej. Powyższe rozważania prowadzą do wniosku, że skarżący będący obywatelem polskim, wskutek odmowy transkrypcji zagranicznego aktu urodzenia, nie może korzystać z praw podmiotowych przysługujących innym osobom posiadającym polskie obywatelstwo.

\section{UCHWALA SKŁADU SIEDMIU SĘDZIÓW II OPS 1/19 I JEJ ZNACZENIE}

Wskazane w orzecznictwie sądów administracyjnych rozbieżności w kwestii transkrypcji zagranicznego aktu urodzenia dziecka, w którym jako rodzice są wpisane osoby tej samej płci, dały składowi orzekającemu w sprawie II OSK 1330/17 asumpt do skorzystania z trybu przewidzianego w art. 187 § 1 ustawy z dnia 30 sierpnia 2002 r. - Prawo o postępowaniu przed sądami administracyjnymi (Dz. U. z 2019 r., poz. 2325, ze zm.). Przedmiotem rozpoznawanej sprawy była odmowa organu wpisania do polskiego rejestru stanu cywilnego brytyjskiego aktu urodzenia dziecka, w którym jako rodzice figurują dwie kobiety. Wcześniej skarżąca wszczęła postępowanie o wydanie paszportu dla małoletniego dziecka, które pozostawiono bez rozpoznania z powodu braku możliwości przedstawienia odpisu polskiego aktu urodzenia. Postanowieniem z 17 kwietnia 2019 r. przedstawiono składowi siedmiu sędziów NSA następujące zagadnienie prawne:

Czy przepis art. 104 ust. 5 i art. 107 pkt 3 ustawy z dnia 28 listopada 2014 r. Prawo o aktach stanu cywilnego (Dz. U. z 2014 r. poz. 1741 ze zm.) w związku z art. 7 ustawy z dnia 4 lutego 2011 r. Prawo prywatne międzynarodowe (Dz. U. z 2015 r. poz. 1792), dopuszcza transkrypcję zagranicznego aktu urodzenia dziecka, w którym jako rodzice wpisane są osoby tej samej płci.

W uchwale z 2 grudnia 2019 r., II OPS 1/19 skład siedmiu sędziów NSA orzekł, że:

Przepis art. 104 ust. 5 i art. 107 pkt 3 ustawy z dnia 28 listopada 2014 r. Prawo o aktach stanu cywilnego (Dz. U. z 2014 r. poz. 1741, ze zm.) w związku z art. 7 ustawy z dnia 4 lutego 2011 r. Prawo prywatne międzynarodowe (Dz. U. z 2015 r. poz. 1792) nie dopuszcza transkrypcji zagranicznego aktu urodzenia dziecka, w którym jako rodzice wpisane są osoby tej samej płci.

Tym samym przesądzono, że polskie prawo nie dopuszcza transkrypcji zagranicznego aktu urodzenia dziecka, w którym jako rodzice wpisane są osoby tej samej płci ${ }^{22}$.

Skład siedmiu sędziów NSA rozważył kwestie dopuszczalności rejestracji w polskich aktach stanu cywilnego pochodzenia dziecka od dwóch osób tej samej płci, bazując na zasadach i wartościach konstytucyjnych oraz międzynarodowych, jak również wynikających z prawa Unii Europejskiej. Dokonano również

${ }^{22}$ Zob. omówienie uchwały - Wiącek 2020, 163-172. 
wnikliwej egzegezy przepisów prawa krajowego, w tym także w kontekście orzecznictwa Trybunału Sprawiedliwości UE i ETPC.

Przede wszystkim, uzasadniając uchwałę, NSA zwrócił uwagę, że w wyniku transkrypcji powstaje polski akt stanu cywilnego, który pod względem mocy dowodowej nie różni się od aktu stanu cywilnego powstałego na podstawie rejestracji zdarzenia prawnego. Wpisanie do polskiego rejestru stanu cywilnego w drodze transkrypcji dwóch kobiet jako rodziców dziecka stanowiłoby naruszenie podstawowych zasad polskiego porządku prawnego, ponieważ w prawie polskim rodzicami dziecka mogą być tylko matka i ojciec. Podkreślono, że ,prawo polskie nie zna instytucji »rodziców jednopłciowych« i nie przyznaje związkom partnerskim praw rodzicielskich".

Skład siedmiu sędziów NSA zaznaczył, że

klauzula porządku publicznego wymieniona w art. 107 pkt 3 Prawa o aktach stanu cywilnego, tak jak klauzula wyrażona w art. 7 Prawo prywatne międzynarodowe, stanowi zabezpieczenie przed skutkami zastosowania prawa obcego przewidującego rozwiązania sprzeczne z podstawowymi zasadami i wartościami akceptowanymi w polskim porządku prawnym. Klauzula porządku publicznego gwarantuje ochronę krajowego porządku prawnego przed jego naruszeniem w postaci nadania skuteczności (uznania) aktu stanu cywilnego nieodpowiadającemu fundamentalnym zasadom porządku prawnego. W ramach przesłanki porządku publicznego badaniu podlegają skutki prawne uznania danego aktu. Nie chodzi przy tym o samą sprzeczność zagranicznego aktu stanu cywilnego z podstawowymi zasadami porządku prawnego, ale o to, by skutki transkrybowania takiego aktu były nie do pogodzenia $\mathrm{z}$ tymi zasadami.

Jednocześnie NSA podkreślił, że - ze względu na art. 34 ust. 1 zd. 1 Konstytucji ${ }^{23}$ - brak transkrypcji aktu urodzenia nie stanowi przeszkody do potwierdzenia posiadania obywatelstwa polskiego ${ }^{24}$. W uzasadnieniu NSA stwierdził, że

prawidłowa wykładnia art. 104 ust. 5 ustawy Prawo o aktach stanu cywilnego nie może prowadzić do uzależnienia uzyskania przez obywatela polskiego dowodu tożsamości albo numeru PESEL od dokonania przez organ transkrypcji, która nie jest możliwa tylko z tego powodu, że w zagranicznym akcie urodzenia dziecka podano zamiast danych ojca dane kobiety, która pozostaje w nieznanym polskiemu prawu związku partnerskim z matką dziecka będącą obywatelką polską.

Akt urodzenia, nawet bez jego transkrypcji, jest wyłącznym dowodem zdarzeń w nim stwierdzonych. W konsekwencji, zdaniem NSA, „dziecko skarżącej może [...] powołać się na taki akt w postępowaniu administracyjnym i sądowym, a także realizować uprawnienia, których nabycie jest uzależnione od wykazania aktu stanu cywilnego, nawet gdyby nie dokonano jego transkrypcji" 25 .

${ }^{23}$ „Obywatelstwo polskie nabywa się przez urodzenie z rodziców będących obywatelami polskimi".

${ }^{24}$ Por. wyroki NSA: z dnia 6 maja 2015 r., II OSK 2372/12; z dnia 30 października 2018 r., II OSK 1868/16. Zob. Mostowik 2018, 55-75.

${ }^{25}$ Sąd odwołał się do uchwały składu siedmiu sędziów Sądu Najwyższego z dnia 20 listopada 2012 r., III CZP 58/12, OSNC 2013, nr 5, poz. 55. 
Powołując się na orzecznictwo TSUE ${ }^{26}$, NSA podkreślił, że ustawodawstwo dotyczące stanu cywilnego mieści się w kompetencjach państw członkowskich i prawo UE nie narusza tej kompetencji. Jednak brak harmonizacji przepisów dotyczących stanu cywilnego na poziomie unijnym (a także międzynarodowym) powoduje, że rozwiązania przyjęte w tym zakresie w poszczególnych państwach członkowskich różnią się zarówno co do treści, jak i formy oraz zakresu danych ujawnianych w krajowych rejestrach stanu cywilnego. Zwraca uwagę, że prawo UE nie przewiduje bezwzględnego obowiązku uznania skutków zagranicznego aktu stanu cywilnego oraz jego przeniesienia do krajowego rejestru stanu cywilnego. Odmowa przeniesienia zagranicznego dokumentu do krajowego rejestru stanu cywilnego może być uzasadniona zastosowaniem krajowej klauzuli porządku publicznego. Trybunał Sprawiedliwości dostrzegł, że rozstrzyganie kwestii związanych z przeniesieniem do krajowego rejestru stanu cywilnego danych wynikających z zagranicznego dokumentu urzędowego wymaga poszanowania słusznej równowagi sprzecznych interesów, tj. z jednej strony, ochrony uprawnień wynikających z prawa UE, oraz z drugiej strony - uzasadnionej ochrony przez państwo członkowskie jego tradycji ${ }^{27}$.

W motywach uchwały NSA odwołał się do orzecznictwa ETPC ${ }^{28}$, ze szczególnym uwzględnieniem pierwszej opinii doradczej wielkiej izby Trybunału z dnia 10 kwietnia 2019 r. Sąd zaznaczył jednak, że powołane w uzasadnieniu wyroki ETPC, w odróżnieniu od sprawy, w której doszło do zadania pytania składowi siedmiu sędziów, dotyczą prawnego uznania umowy o macierzyństwo zastępcze lub zawarcia związku partnerskiego osób tej samej płci. Rozpoznawana przez NSA sprawa dotyczyła natomiast transkrypcji zagranicznego aktu stanu cywilnego, w którym jako rodziców wskazano osoby tej samej płci, a nie dwupłciowych rodziców pozostających w związku małżeńskim. Poza tym, w rozpoznawanej sprawie nie powstały wątpliwości co do nabycia obywatelstwa polskiego przez dziecko skarżącej lub praw rodzicielskich przez matkę dziecka. Jak zaznaczył NSA, z orzecznictwa ETPC nie wynika generalny obowiązek transkrypcji zagranicznych aktów urodzenia dzieci, których jedno z rodziców pozostaje w jednopłciowym związku partnerskim, uznawanym w kraju wystawienia aktu urodzenia, a nieuznawanym

${ }^{26}$ Wyroki TSUE: z dnia 2 października 2003 r. w sprawie C-148/02 Garcia Avello, ECLI:EU:C:2003:539, pkt 25; z dnia 1 kwietnia 2008 r. w sprawie C-267/06 Maruko, ECLI:EU:C:2008:179, pkt 59; z dnia 14 października 2008 r. w sprawie C-353/06 Grunkin i Paul, ECLI:EU:C:2008:559, pkt 16.

${ }^{27}$ Wyrok TSUE z dnia 12 maja 2011 r. w sprawie C-391/09 Runevič-Vardyn i Wardyn, ECLI:EU:C:2011:291, pkt 91.

${ }^{28}$ Wyroki ETPC: z dnia 26 czerwca 2014 r. w sprawie Mennesson przeciwko Francji, skarga nr 65192/11, HUDOC; z dnia 26 czerwca 2014 r. w sprawie Labassee przeciwko Francji, skarga nr 65941/11, HUDOC; z dnia 24 stycznia 2017 r. w sprawie Paradiso i Campanelli przeciwko Wtochom, skarga nr 25358/12, HUDOC; z dnia 14 grudnia 2017 r. w sprawie Orlandi i in. przeciwko Włochom, skargi nr 26431/12, 26742/12, 44057/12 i 60088/12, HUDOC; z dnia 21 lipca 2015 r. w sprawie Oliari i inni przeciwko Włochom, skargi nr 18766/11 i 36030/11, HUDOC. 
w państwie, które jest stroną EKPC. Skład siedmiu sędziów stwierdził, że to nie sama odmowa transkrypcji aktu urodzenia dziecka może powodować odpowiedzialność państwa za naruszenie Konwencji, ale jej skutki i brak ochrony przed negatywnymi konsekwencjami braku transkrypcji. Co więcej, skutki te podlegać będą ocenie w odrębnych indywidualnych postępowaniach, np. w związku z ewentualną odmową wydania dowodu tożsamości. W związku z tym - w ocenie NSA - zarzuty nieuwzględnienia interesów dziecka i naruszenia ochrony praw dziecka wynikających z Konwencji o prawach dziecka, a także postanowień Konstytucji powinny być brane pod uwagę $\mathrm{w}$ razie odmowy transkrypcji w tych właśnie postępowaniach. Jak podkreślono, odmowa dokonania transkrypcji z powodu naruszenia zasad polskiego porządku prawnego nie jest równoznaczna z naruszeniem konstytucyjnego i międzynarodowego obowiązku władz publicznych do uwzględnienia najlepszego interesu dziecka, gdyż zagraniczny akt urodzenia, nawet bez jego transkrypcji, jest wyłącznym dowodem zdarzeń w nim stwierdzonych i dziecko skarżącej może powołać się na taki akt w postępowaniach administracyjnych i sądowych, które dotyczą jego praw.

Uchwała składu siedmiu sędziów NSA wydana w trybie art. $187 \S 1$ ustawy - Prawo o postępowaniu przed sądami administracyjnymi, zawierająca rozstrzygnięcie zagadnienia prawnego budzącego poważne wątpliwości w konkretnej sprawie administracyjnej, ,jest w danej sprawie wiążąca”, tj. w całym dalszym postępowaniu aż do jego prawomocnego zakończenia ${ }^{29}$. Oznacza to, że sąd, który skierował pytanie do składu powiększonego w trakcie rozpoznawania skargi kasacyjnej, nie ma możliwości odstąpienia od oceny wyrażonej w uchwale składu powiększonego NSA, stanowiącej odpowiedź na zadane pytanie. Wynika to stąd, że zawarta w takiej uchwale wykładnia dokonywana jest w ścisłym związku z postępowaniem toczącym się w konkretnej sprawie. Wykładnia przepisów wskazanych przez skład orzekający polega na ustaleniu ich prawidłowego rozumienia, w celu zrekonstruowania normy prawnej, która ma zastosowanie w rozpoznawanej przez sąd sprawie. Niemniej jednak tego rodzaju uchwały - konkretne - powinny przyczynić się do zapewnienia jednolitości wykładni obowiązujących przepisów przez sądy administracyjne. Wykładnia sądowa współtworzy bowiem sens przepisów prawnych, a kluczowe znaczenie ma w tym zakresie reguła ogólna zawarta w sentencji lub uzasadnieniu uchwały. Co istotne, reguła ogólna nie tylko wiąże w danej sprawie, jest również podstawą, wzorcem i modelem stosowanym przy orzekaniu w podobnych sprawach w przyszłości. Dokonana w uchwale składu siedmiu sędziów NSA wykładnia przepisów prawa krajowego ma znaczenie zarówno w aspekcie zapewnienia spójności systemu prawnego, jak i jednolitości orzecznictwa sądowego, zważywszy że sądy jako takie ustawodawcy zastępować nie mogą.

${ }^{29}$ Zob. uchwałę składu siedmiu sędziów NSA z dnia 13 października 2003 r., OPS 5/03; por. Skoczylas 2004, 227-229. 
Wydany w dniu 11 lutego 2020 r. wyrok w sprawie II OSK 1330/17 uwzględnia wprost treść uchwały II OPS $1 / 19$, uznającej za sprzeczną z podstawowymi zasadami prawa rodzinnego transkrypcję aktu urodzenia, w którym jako rodzice wpisane zostały osoby tej samej płci.

\section{PODSUMOWANIE}

Na podstawie wskazanych przykładów z orzecznictwa polskich sądów administracyjnych można stwierdzić, że rozstrzyganie sporów o prawo mających charakter transgraniczny wymaga od sędziego nie tylko szczególnej wiedzy prawniczej, ale i umiejętności sprawnego rozwiązywania konfliktów czy kolizji norm prawnych, w tym także kolizji systemów prawnych. Sprawy transkrypcji zagranicznych aktów urodzenia dzieci, w których jako rodzice wpisane są osoby tej samej płci, podobnie jak sprawy potwierdzenia posiadania obywatelstwa polskiego, stały się dla sądów administracyjnych okazją do pogłębionych analiz. Wykładnia znajdujących zastosowanie w tych sprawach przepisów prawa wymagała operatywnego wyjaśnienia - w realiach poszczególnych spraw - znaczenia klauzul generalnych (dobro dziecka, porządek publiczny) lub praw (prawo do obywatelstwa, prawo do prywatności, zakaz dyskryminacji) czy gwarancji zawartych w konstytucji oraz w aktach prawa międzynarodowego.

Nie ulega wątpliwości, że umiejscowienie zagranicznego aktu stanu cywilnego w polskim obrocie prawnym w kontekście prawa do obywatelstwa dziecka, w którego akcie urodzenia jako rodzice wpisane są osoby tej samej płci, a jedno z rodziców jest obywatelem Rzeczypospolitej, to kwestia wysoce newralgiczna, gdyż wiąże się tożsamością dziecka. Zawarta w uzasadnieniu uchwały II OPS 1/19 argumentacja zdaje się przekonywać co do wyboru takiego sposobu rozumienia art. 104 ust. 5 ustawy - Prawo o aktach stanu cywilnego, według którego brak transkrypcji zagranicznego aktu urodzenia nie stanowi przeszkody do potwierdzenia posiadania obywatelstwa polskiego. Takie stanowisko jest spójne z sentencją uchwały o niedopuszczalności - z uwagi na podstawowe zasady porządku prawnego Rzeczypospolitej Polskiej - transkrypcji zagranicznego aktu urodzenia dziecka, w którym jako rodzice wpisane są osoby tej samej płci. Odmowa dokonania transkrypcji z powodu naruszenia zasad polskiego porządku prawnego nie jest bowiem - zdaniem NSA - równoznaczna z naruszeniem konstytucyjnego i międzynarodowego obowiązku władz publicznych do uwzględnienia najlepszego interesu dziecka. Racjonalne jest założenie, że szczegółowe sprawy administracyjne, takie jak sprawy o wydanie paszportu, nadanie numeru PESEL czy stwierdzenie posiadania obywatelstwa polskiego, mogą de lege lata zostać załatwione niezależnie od tego, czy organ dokona transkrypcji zagranicznego aktu urodzenia. W ten sposób zabezpieczone zostają, z jednej strony, indywidualny interes dziecka obywatela polskiego, a z drugiej - efektywność podstawowych zasad krajowego porządku prawnego. 


\section{BIBLIOGRAFIA}

Borysiak, Witold. 2016. „Komentarz do art. 18”. W Leszek Bosek, Marek Safjan (red.). Konstytucja RP, T. I. Komentarz do art. 1-86. 464-495. Warszawa: Wydawnictwo C.H. Beck.

Chmielarz-Grochal, Anna, Kalisz, Anna. 2020. „Realizacja konwencyjnych standardów prawa do sądu przez sądy administracyjne”. Państwo i Prawo 1: 71-94.

Florjanowicz-Błachut, Przemysław. 2020. Zeszyty Naukowe Sadownictwa Administracyjnego 1: $107-118$.

Garlicki, Leszek. 2016. „Komentarz do art. 18”. W Leszek Garlicki, Marek Zubik (red.). Konstytucja Rzeczypospolitej Polskiej. Komentarz. T. I. 489-505. Warszawa: Wydawnictwo Sejmowe.

Hauser, Roman, Niewiadomski, Zygmunt, Wróbel, Andrzej. 2012. System prawa administracyjnego. T. 2. Konstytucyjne podstawy funkcjonowania administracji publicznej. Warszawa: Wydawnictwo C.H. Beck.

Leszczyński, Leszek. 2010. „Orzekanie przez sądy administracyjne a wykładnia prawa”. Zeszyty Naukowe Sadownictwa Administracyjnego 5-6: 267-279.

Łętowska, Ewa. 2005a. „Między Scyllą a Charybdą - sędzia polski między Strasburgiem i Luksemburgiem". Europejski Przegląd Sadowy 1: 3-10.

Łętowska, Ewa. 2005b. „Multicentryczność współczesnego systemu prawa i jej konsekwencje”. Państwo i Prawo 4: 3-10.

Mostowik, Piotr. 2018. „Problem obywatelstwa dziecka prawdopodobnie pochodzącego od obywatela polskiego niebędącego mężem surrogate mother. Uwagi aprobujące wyroki NSA z 6 maja 2015 r. (II OSK 2372/13 i II OSK 2419/13)”. Problemy Współczesnego Prawa Międzynarodowego, Europejskiego i Porównawczego 16: 55-75.

Mostowik, Piotr. 2019. Problem rejestracji w polskich aktach urodzenia pochodzenia dziecka od ,rodziców jednopłciowych” na tle orzecznictwa sądów administracyjnych w 2018 r. Warszawa: Instytut Wymiaru Sprawiedliwości.

Skoczylas, Andrzej. 2004. Działalność uchwałodawcza Naczelnego Sądu Administracyjnego. Warszawa: Wydawnictwo C.H. Beck.

Wiącek, Marcin. 2020. Zeszyty Naukowe Sadownictwa Administracyjnego 1: 163-172.

\section{AKTY PRAWNE}

Konstytucja Rzeczypospolitej Polskiej z dnia 2 kwietnia 1997 r. (Dz. U., nr 78, poz. 483 ze zm.).

Konwencja o ochronie praw człowieka i podstawowych wolności sporządzona w Rzymie dnia 4 listopada 1950 r., zmieniona następnie Protokołami nr 3, 5 i 8 oraz uzupełniona Protokołem nr 2 (Dz. U. z 1993 r., nr 61, poz. 284, ze zm.).

Konwencja o prawach dziecka przyjęta przez Zgromadzenie Ogólne Narodów Zjednoczonych dnia 20 listopada 1989 r. (Dz. U. z 1991 r., nr 120, poz. 526, ze zm.).

Ustawa z dnia 25 lutego 1964 r. - Kodeks rodzinny i opiekuńczy (Dz. U. z 2020 r., poz. 1359).

Ustawa z dnia 17 listopada 1974 r. - Kodeks postępowania cywilnego (Dz. U. z 2020 r., poz. 1575, ze zm.).

Ustawa z dnia 30 sierpnia 2002 r. - Prawo o postępowaniu przed sądami administracyjnymi (Dz. U. z 2019 r., poz. 2325, ze zm.).

Ustawa z dnia 4 lutego 2011 r. - Prawo prywatne międzynarodowe (Dz. U. z 2015 r., poz. 1792).

Ustawa z dnia 28 listopada 2014 r. - Prawo o aktach stanu cywilnego (Dz. U. z 2020 r., poz. 463, ze zm.).

\section{ORZECZNICTWO}

Decyzja ETPC z dnia 12 stycznia 1999 r. w sprawie Karassev przeciwko Finlandii, skarga nr 31414/96, HUDOC. 
Opinia doradcza ETPC (wielka izba) z dnia 10 kwietnia 2019 r., wniosek nr P16-2018-001, HUDOC.

Wyrok ETPC z dnia 24 czerwca 2010 r., Schalk i Kopf przeciwko Austrii, skarga nr 30141/04, HUDOC.

Wyrok ETPC z dnia 11 października 2011 r. w sprawie Genovese przeciwko Malcie, skarga nr 53124/09, HUDOC.

Wyrok ETPC z dnia 12 marca 2014 r. w sprawie Kurić i inni przeciwko Stowenii, skarga nr 26828/06, HUDOC.

Wyrok ETPC z dnia 26 czerwca 2014 r. w sprawie Labasse przeciwko Francji, skarga nr 65941/11, HUDOC.

Wyrok ETPC z dnia 26 czerwca 2014 r. w sprawie Mennesson przeciwko Francji, skarga nr 65192/11, HUDOC.

Wyrok ETPC z dnia 21 lipca 2015 r. w sprawie Oliari i inni przeciwko Włochom, skargi nr 18766/11 i 36030/11, HUDOC.

Wyrok ETPC z dnia 24 stycznia 2017 r. w sprawie Paradiso i Campanelli przeciwko Włochom, skarga $\mathrm{nr}$ 25358/12, HUDOC.

Wyrok ETPC z dnia 14 grudnia 2017 r. w sprawie Orlandi $i$ in. przeciwko Włochom, skargi nr 26431/12, 26742/12, 44057/12 i 60088/12, HUDOC.

Wyrok TSUE z dnia 2 października 2003 r. w sprawie C-148/02 Garcia Avello, ECLI:EU:C:2003:539.

Wyrok TSUE z dnia 1 kwietnia 2008 r. w sprawie C-267/06 Maruko, ECLI:EU:C:2008:179.

WyrokTSUEzdnia 14 października 2008 r.w sprawieC-353/06 Grunkini Paul,ECLI:EU:C:2008:559.

Wyrok TSUE z dnia 12 maja 2011 r. w sprawie C-391/09 Runevič-Vardyn $i$ Wardyn, ECLI:EU:C:2011:291.

Wyrok TSUE z dnia 2 czerwca 2016 r. w sprawie C-438/14 Bogendorff von Wolffersdorff, ECLI:EU:C:2016:401.

Wyrok TSUE z dnia 13 lipca 2017 r. w sprawie C-193/16 E przeciwko Subdelegación del Gobierno en Álava, ECLI:EU:C:2017:542.

Wyrok TSUE z dnia 5 czerwca 2018 r. w sprawie C-673/16 Coman, ECLI:EU:C:2018:385.

Uchwała składu siedmiu sędziów SN z dnia 20 listopada 2012 r., III CZP 58/12, OSNC 2013, nr 5, poz. 55.

Postanowienie SN z dnia 8 maja 2015 r., III CSK 296/14, LEX nr 1712817.

Uchwała składu siedmiu sędziów NSA z dnia 13 października 2003 r., OPS 5/03.

Uchwała składu siedmiu sędziów NSA z dnia 2 grudnia 2019 r., II OPS 1/19.

Wyrok NSA z dnia 17 grudnia 2014 r., II OSK 1298/13.

Wyrok NSA z dnia 6 maja 2015 r., II OSK 2372/12.

Wyrok NSA z dnia 20 czerwca 2018 r., II OSK 1808/16.

Wyrok NSA z dnia 29 sierpnia 2018 r., II OSK 2129/16.

Wyrok NSA z dnia 10 października 2018 r., II OSK 2552/16.

Wyrok NSA z dnia 30 października 2018 r., II OSK 1868/16.

Wyrok NSA z dnia 11 lutego 2020 r., II OSK 1330/17.

Postanowienie NSA z dnia 17 kwietnia 2019 r., II OSK 1330/17.

Wyrok WSA w Gliwicach z dnia 6 kwietnia 2016 r., II SA/Gl 1157/15.

Wyrok WSA w Warszawie z dnia 14 kwietnia 2016 r., IV SA/Wa 182/16.

Wyrok WSA w Krakowie z dnia 10 maja 2016 r., III SA/Kr 1400/15.

Wyrok WSA w Poznaniu z dnia 5 kwietnia 2018 r., II SA/Po 1169/17. 